\title{
The Development of Entrepreneurship Training Model, Mentoring and Bookkeeping Fostering for Furniture Craftsmen in East Java, Indonesia
}

\author{
Etta Mamang Sangadji (Corresponding author) \\ STKIP PGRI Pasuruan, Indonesia \\ Email: sangadji_23@yahoo.com
}

\author{
Dr. Sopiah
}

State University of Malang, Indonesia

Doi:10.5296/ ijld.v5i3.8219 URL: http://dx.doi.org/10.5296/ ijld.v5i3.8219

\begin{abstract}
The research objective is to find out The Model of Entrepreneurship Training, Mentoring and Bookkeeping Fostering for furniture craftsmen in Pasuruan regency and municipality, Indonesia. With purposive technique, there was research sample of 100 furniture craftmen in Pasuruan regency and municipality; the data collection method applied questionnaires, interviews and documentation. The procedure of model development used Borg and Gall (1983) as following: Research and collection of information, Planning, Initial Product Development (models draft), Initial Tests, Products Revision, Limited Field Trials, Product Revision, Field Trials, Revision of the Final Product, Model Implementation. Data analysis technique applied descriptive statistical analysis. The results of the research is a model of entrepreneurship training, mentoring and bookkeeping fostering for furniture craftsmen, which are arranged in the form of textbooks, containin guidelines for training, mentoring and bookkeeping simple guidelines for furniture craftsmen.
\end{abstract}

Keywords: Entrepreneurship Training Model 


\section{Introduction}

Pasuruan regency and municipality is a central area of wooden handicrafts especially products of teak woods like wardrobe, bookcase, cupboard, guest table and chairs, dining tables and chairs etc. The products of this region have reached to the rest of Indonesia even to foreign countries. There are two types of products produced in the form of finished products and semi-finished products. Product marketing place is located in Bukir village, an area on the edge of Pasuruan municipality, including Pasuruan regency area. In Bukir there are about 300 stores selling the entire teak product both finished products and semi-finished products. In this business there are two main actors, namely the marketer (Employers) and the second is craftsmen. The craftsmen are scattered around Pasuruan regency and municipality. The craftsmen usually produce semi-finished materials after that tey sell to the market themselves if the goods belong to them, but they only get wages from employers if the raw material for making household appliances came from shopkeepers. The results of a recent survey by researcher indicated that the number of craftsmen involved in this business about 2500 people. Where around 2000 people are just as craftmen and receive average wage of Rp 150,000,- per week, meanwhile the remaining 500 craftmen are small entrepreneurs for half-finished products.

The problem is that up to now until now the welfare level of craftmen is still far from a decent life because they only received a wage of $\mathrm{Rp} 30,000$,- per day then they will earn around Rp 900,000,- per month. Whereas it has been the characteristic of lower class society that the number of family members covered is very many. So with the amount of revenue received will not be able to cover the needs of day-to-day living expenses, let alone to finance their children's school. Poverty circle like this is not going to break if there is no emergency effort to cut it. The efforts to do is improving ability and capacity of the business in order to be able to obtain greater income. For craftsmen who also serve as small entrepreneurs, since the products produced in the form of semi-finished goods, the price of product sales is very cheap and the profit margin obtained much smaller if the product is sold in the form of finished products. In fact, if the products are not salable then usually on Saturday semi-finished products will be sold at a very low price, because it is driven by the need to get cash to pay the loan capital and to finance the needs of everyday life. With this reason the researchers want to conduct training assistance in the field of entrepreneurship and bookkeeping so that the craftsmen can go up the class into a businessman and can manage the books in an orderly manner so that future efforts would be better, which in turn will increase the level of income.

With the training in the field of entrepreneurship, craftmen can gain an insight into the development of enterprises, how they should obtain capital, how they should build a network of business, how they must serve customers with satisfactory service. Because based on the results of our observations, the aspect is very weak of the craftsmen. They seemed resigned to the fate that is, that they were destined by God to remain as craftsmen. While in training on simple bookkeeping at least the craftsman should be able to separate personal property from assets of company (business), how to book revenue and costs in an orderly manner so that within a certain period they will be able to calculate how much profit or loss which they 


\section{MInstitute Macrothin}

International Journal of Learning \& Development

ISSN 2164-4063

obtained. Usually they spent entire earned income, which when gets high income then they becomes wasteful but if obtaining a small income they will be indebt with third parties. Thus efforts to transform entrepreneurial behavior is becoming a necessity.

The general objective of this research is to produce a model of Entrepreneurship Training for furniture craftsmen in Pasuruan regency and municipality. Meanwhile the specific objectives of research are: (1) To know the process of developing a model of entrepreneurship training, business planning and bookkeeping fostering for furniture craftsmen in Pasuruan regency and municipality (2) To determine the final outcome model of entrepreneurship training, business planning and bookkeeping fostering for furniture craftsmen in Pasuruan regency and municipality which includes the implementation of a training guide, training syllabus and training materials (3) To find out the implementation of entrepreneurship training, business planning and bookkeeping fostering for furniture craftsmen in Pasuruan regency and municipality.

\section{Research Methodology}

The research variables are the development of entrepreneurship training model, mentoring and bookkeeping fostering for furniture craftmen in Pasuruan regency and municipality. With purposive sampling techniques, it was determined 100 furniture craftsmen, data collection method using questionnaires, interviews and documentation. The procedure of development adopted the modelof Borg \& Gohl (1983). The data analysis applied descriptive analysis.

\section{Research Findings}

\section{A. Descriptive Analysis on the Characteristics of Respondents}

\section{Demographic Description on the Participants of Entrepreneurship Training and} Furniture Craftsman Bookkeeping.

After going through the selection process, the obtained 100 participants with qualification predetermined. Forthermore the following is presented demographic description consisting of education level, gender of respondents, the area of origin of the respondents, the level of education of the respondents, the level of monthly income, family size, age of participants and the width of field owned, participation in education and training, understanding of entrepreneurship and understanding of the business plan.

\section{Table 1. Respondents' Gender}

\begin{tabular}{|l|l|l|l|}
\hline No & Explanation & Total & $\%$ \\
\hline 1 & Male & 100 & 100 \\
\hline 2 & Female & - & - \\
\hline & Total & 100 & $100 \%$ \\
\hline
\end{tabular}


Source: Processed Primary Data (August 2015)

From the table above it is found out that the number of respondents are all male. These data demonstrated up to now the people of Pasuruan regency and municipality still adhere to Islamic religious values particularly the view that the one who must earn a living is male or husband. This information was also in line with the researchers' brief interviews with some of the furniture craftsmen.

Table 2. Respondents' Education Level

\begin{tabular}{|l|l|l|l|}
\hline No & Explanation & Total & $\%$ \\
\hline 1 & Elementary School & 30 & 30 \\
\hline 2 & Junior High School & 40 & 40 \\
\hline 3 & Senior High School & 25 & 25 \\
\hline 3 & University & 5 & 5 \\
\hline & Total & 100 & 100 \\
\hline
\end{tabular}

Source: Processed Primary Data (August 2015)

From the data above data, there is information that most of number of respondents have elementary and secondary education, namely about $70 \%$. While $25 \%$ had high school and university evel as much as $5 \%$.

Table 3. Respondents' Age

\begin{tabular}{|l|l|l|l|}
\hline No & Explanation & Total & $\%$ \\
\hline 1 & $17-30$ years old & 65 & 65 \\
\hline 2 & $31-40$ years old & 32 & 32 \\
\hline 3 & Above 40 years old & 3 & 3 \\
\hline & Total & 100 & 100 \\
\hline
\end{tabular}

Source: Processed Primary Data (August 2015) 


\section{Macrothink}

From the table above it is known that most respondents' ages ranged between 17-30 years old for 65 people, followed with 31-40 years old as many as 32 people and above 40 years old as many as three people. This means that the age of the furniture craftsmen in general is at the productive age.

\section{Table 4 The Number of Children Covered}

\begin{tabular}{|l|l|l|l|}
\hline No & Explanation & Total & $\%$ \\
\hline 1 & $1-2$ persons & 43 & 43 \\
\hline 2 & $3-4$ persons & 45 & 45 \\
\hline 3 & Above 5 persons & 12 & 12 \\
\hline & Total & 100 & 100 \\
\hline
\end{tabular}

Source: Processed Primary Data (August 2015)

From the data above it is known that the average respondent in this study had dependent children between 3-4 persons, quite a lot which is about 45 people, while the remaining 43 people who have the children between 1-2 and followed 12 people with covered children over 5 people. This means that with a minimal amount of revenue, many craftsmen have to bear the considerable number of children.

Table 5 Respondents' Income Level

\begin{tabular}{|l|l|l|l|}
\hline No & Explanation & Total & $\%$ \\
\hline 1 & Under Rp 300.000 & 35 & 25 \\
\hline 2 & Rp 310.000,- - Rp 500.000,- & 25 & 40 \\
\hline 5 & Above Rp 500.000 & 40 & 35 \\
\hline & Total & 100 & 100 \\
\hline
\end{tabular}

Source: Processed Primary Data (August 2015)

Respondents' income level is still low on average, namely $\operatorname{Rp} 310,000$, - - Rp 500,000, - for 25 people, followed with under $\$ 300,000$, - for 35 people and above $\mathrm{Rp} 500,000$ for 40 people. This means that most of the furniture craftsmen are still poor, their revenue number is 
still far from the regional minimum wage for East Java, which around Rp 1.000.000, -. Thus various efforts to increase the revenue of furniture craftsmen should always be carried out.

Table 6 Furniture Business Ownership

\begin{tabular}{|l|l|l|l|}
\hline No & Explanation & Total & $\%$ \\
\hline 1 & Self Ownership & 27 & 27 \\
\hline 2 & Laborer Only & 73 & 73 \\
\hline & Total & 100 & 100 \\
\hline
\end{tabular}

Source: Processed Primary Data (August 2015)

From the table above, it is known that furniture craftsmen also serving as business owners are ony $27 \%$, while the remaining $73 \%$ is just as laborers. Thus the attempt to empower them to be able to develop into new entrepreneurs are needed.

Table 7 Participation in Entrepreneurship Education and Training, Business Desin and Bookkeeping

\begin{tabular}{|l|l|l|l|}
\hline No & Explanation & Total & $\%$ \\
\hline 1 & Ever joined training & 98 & 98 \\
\hline 2 & Never joined training & 2 & 2 \\
\hline & Total & 100 & 100 \\
\hline
\end{tabular}

Source: Processed Primary Data (August 2015)

From the table above, it is known that most of the participants had never participate in education and training in the field of entrepreneurship, business planning and bookkeeping. The number of those who had attended the training is only $2 \%$, while about $98 \%$ have not been trained. 


\section{Ml Macrothink \\ International Journal of Learning \& Development

Table 8 Respondents' Understanding about Entrepreneurship

\begin{tabular}{|l|l|l|l|}
\hline No & Explanation & Total & $\%$ \\
\hline 1 & Not Understand & 78 & 78 \\
\hline 2 & Quite Understand & 22 & 22 \\
\hline 3 & Understand & 2 & 2 \\
\hline 4 & Totally Understand & - & - \\
\hline & Total & 100 & 100 \\
\hline
\end{tabular}

Source: Processed Primary Data (August 2015)

From the table above it is known that most of the respondents did not understand the entrepreneurial problem, namely about $78 \%$, while about $22 \%$ said quite understand and who understand are only $2 \%$.

Table 9 Respondents' Understanding on Business plans

\begin{tabular}{|l|l|l|l|}
\hline No & Explanation & Total & $\%$ \\
\hline 1 & Not Understand & 97 & 97 \\
\hline 2 & Quite Understand & 3 & 3 \\
\hline 3 & Understand & - & - \\
\hline 4 & Totally Understand & - & - \\
\hline & Total & 100 & 100 \\
\hline
\end{tabular}

Source: Processed Primary Data (August 2015)

From the table above it is known that about $97 \%$ of the respondents stated that they do not understand what it is about business plans while the remaining 3\% stated quite understand. 
Table 10. Respondents' Understanding on Simple Bookkeeping

\begin{tabular}{|l|l|l|l|}
\hline No & Explanation & Total & $\%$ \\
\hline 1 & Not Understand & 84 & 84 \\
\hline 2 & Quite Understand & 16 & 16 \\
\hline 3 & Understand & - & - \\
\hline 4 & Totally Understand & - & - \\
\hline & Total & 100 & 100 \\
\hline
\end{tabular}

Source: Processed Primary Data (August 2015)

From the table above it is known that about $84 \%$ of the respondents stated that they do not understand about what it simple bookkeeping, while the remaining $16 \%$ stated quite understand.

From the description on the characteristics of the respondents above it can be concluded that in general these respondents are economically poor, fairly big number of family member covered, the income is still far from feasible, most of them have not participated in education and training in the field of entrepreneurship, business planning and bookkeeping. It can be concluded that these respondents need to be trained to be able to increase their human qualities, especially in the field of entrepreneurship, business plans and simple bookkeeping.

\section{B. Descriptive Analysis of Respondents' Real Needs}

In the analysis of respondents' real needs, researchers are trying to dig up information from respondents on their real needs of an ideal education and training to improve their skills in the field of entrepreneurship and business plans. Information coverage about the real needs of the participants excavated includes: The level of respondents' need on education and training, respondents' confidence wether if they joined the education and training will improve their ability, willingness to take part in education and training and visits to successful ventures in the field of furniture craft. For more details about the analysis of respondents' real needs on the importance of entrepreneurship training can be described below. 
Table 11 Respondents' Level of Need on Entrepreneurship Knowledge

\begin{tabular}{|l|l|l|l|}
\hline No & Explanation & Total & $\%$ \\
\hline 1 & Desperately Need & 95 & 95 \\
\hline 2 & Need & 5 & 5 \\
\hline 3 & Quite Need & - & - \\
\hline 4 & Less Need & - & - \\
\hline & Total & 100 & 100 \\
\hline
\end{tabular}

Source: Processed Primary Data (August 2015)

From the table above it can be seen the number of respondents who stated in desperate need of entrepreneurship knowledge is 95 people or $95 \%$, the ones who need as many as 5 people or $5 \%$. This means that furniture craftsmen are in dire need and must be held educational activities and training to improve their skills in the field of entrepreneurship.

Table 12. Respondents' Level of Need on Business plans Knowledge

\begin{tabular}{|l|l|l|l|}
\hline No & Explanation & Total & $\%$ \\
\hline 1 & Desperately Need & 97 & 97 \\
\hline 2 & Need & 3 & 3 \\
\hline 3 & Quite Need & - & - \\
\hline 4 & Less Need & - & - \\
\hline & Total & 100 & 100 \\
\hline
\end{tabular}

Source: Processed Primary Data (August 2015)

From the table above, it is known the respondents stated desperately need business plans knowledge are 97 people or $97 \%$ and who stated need are 3 people or 3\%. These data indicate that so far the craftsmen either the craftsmen as owners and just as craftmen are not familiar at all with the business plans. 


\section{Macrothink}

International Journal of Learning \& Development

ISSN 2164-4063

2015, Vol. 5, No. 3

Table 13. The Confidence After Following Entrepreneurship Training May Improve Entrepreneursip Ability

\begin{tabular}{|l|l|l|l|}
\hline No & Explanation & Total & $\%$ \\
\hline 1 & Very Confident & 86 & 86 \\
\hline 2 & Confident & 14 & 14 \\
\hline 3 & Quite Confident & - & - \\
\hline 4 & Less Confident & - & - \\
\hline & Total & 100 & 100 \\
\hline
\end{tabular}

Source: Processed Primary Data (August 2015)

From the table above table, it is known that respondents feel very confident that by following entrepreneurship education and training, it can improve their ability in entrepreneurship, namely 86 people or $86 \%$, while the ones feelconfident are 14 people or $14 \%$.

Table 14. The Confidence After Following Business plans Training May Improve Their Ability in Business plans

\begin{tabular}{|l|l|l|l|}
\hline No & Explanation & Total & $\%$ \\
\hline 1 & Very Confident & 82 & 82 \\
\hline 2 & Confident & 18 & 18 \\
\hline 3 & Quite Confident & - & - \\
\hline 4 & Less Confident & - & - \\
\hline & Total & 100 & 100 \\
\hline
\end{tabular}

Source: Processed Primary Data (August 2015)

The table above shows that about 82 respondents or $82 \%$ said very confident that the business plans training can improve their ability to design furniture, while the ones said confident as many as 18 people or $18 \%$ 
Table 15 Level of Desire to Follow Entrepreneurial and Business plans Training on Furniture

\begin{tabular}{|l|l|l|l|}
\hline No & Explanation & Total & $\%$ \\
\hline 1 & High & 100 & 100 \\
\hline 2 & Want & - & - \\
\hline 3 & Quite & - & - \\
\hline 4 & Less & - & - \\
\hline & Total & 100 & 100 \\
\hline
\end{tabular}

Source: Processed Primary Data (August 2015)

From the table above, it is known that all responses are very eager to follow entrepreneurial training. This means that according to them, it is very important to follow the training in order to boost their ability in entrepreneurship. This information was also confirmed with the interviews we have done to confirm about the answers provided through this questionnaire that they so far have never participated in training activities in the field of entrepreneurship, let alone the one more specific regarding the furniture business.

Table 16. Willingness to Follow Business Consulting after Training

\begin{tabular}{|l|l|l|l|}
\hline No & Explanation & Total & $\%$ \\
\hline 1 & Very Willing & 100 & 100 \\
\hline 2 & Willing & - & - \\
\hline 3 & Quite Willing & - & - \\
\hline 4 & Less Willing & - & - \\
\hline & Total & 100 & 100 \\
\hline
\end{tabular}

Source: Processed Primary Data (August 2015)

From the table above it is known that the respondents are also very excited to participate in 
post-training business consulting. Those who expressed very willing are as many as 100 people or $100 \%$.

\section{Descriptive Analysis on the Need of Bookkeeping Training and Development}

Below are respondents' opinions about the level of need in bookkeeping training and coaching to support the success of their business management

Table 17. The Importance of Learning Simple Bookkeeping Knowledge

\begin{tabular}{|l|l|l|l|}
\hline No & Explanation & Total & $\%$ \\
\hline 1 & Very Important & 94 & 94 \\
\hline 2 & Important & 6 & 6 \\
\hline 3 & Quite Important & - & - \\
\hline 4 & Less Important & - & - \\
\hline & Total & 100 & 100 \\
\hline
\end{tabular}

Source: Processed Primary Data (August 2015)

From the table above there were obtained information that the respondents viewed bookkeeping learning to record his wealth in an orderly manner is very important as much as $94 \%$ and quite important is $6 \%$. While no one stated less important and not important. This means that the respondent deeply requires knowledge of simple bookkeeping to record all the assets, capital, debt and loan. In a limited interview some respondents suggested that this research should followed with training on the subject of entrepreneurship, business planning and bookkeeping. So far, they know what business is and what effort is, but how to manage it better in order to grow more rapidly in the future of their states desperately need the knowledge and intensive guidance of a competent person or institution.

Furthermore below we revealed about the respondents' knowledge about the technical issues of bookkeeping and accounting, in order to obtain information on the respondents' initial capability if the trainin will be planned for the second phase of research. 


\section{Macrothink}

Table 18. The Willingness To be Accompanied in Bookkeeping Fostering

\begin{tabular}{|l|l|l|l|}
\hline No & Explanation & Total & $\%$ \\
\hline 1 & Very Willing & 100 & 100 \\
\hline 2 & Willing & - & - \\
\hline 3 & Quite Willing & - & - \\
\hline 4 & Less Willing & - & - \\
\hline & Total & 100 & 100 \\
\hline
\end{tabular}

Source: Processed Primary Data (August 2015)

From the table above, it is found out that all respondents said willing, accompanied and supervised in the field of bookkeeping to manage their business.

D. Model Bulding on Entrepreneurship Training, Business plans And Bookkeeping Fostering in Furniture Business

From the descriptive data that has been presented above either it concerns especially regarding the characteristics of the respondents as well as their real needs, therefore it can be concluded that they need a training in the field of entrepreneurship especially in the field of entrepreneurship, business planning and bookkeeping fostering. Through interviews with the respondents, data were obtained that so far they manage their business or as a craftsman never based on entrepreneurial spirit and capable of designing their future. They look at the work that was involved during this time can actually turn them into businessman but they don't know where to start.

On the other hand to start a furniture business as their employer, they said they know nothing, deeply need guidance and training on how to manage the business, how to design business, how to set the selling price, where the place of sales, how to calculate profit and loss, etc.

After obtaining the data and analyzing data about individual characteristic and analysis of the real needs of the respondents we then developed a training model for furniture craftsmen in Pasuruan reency and municipality. Pictures of the development model of entrepreneurship training, business plans and bookkeeping fostering can be seen below: 


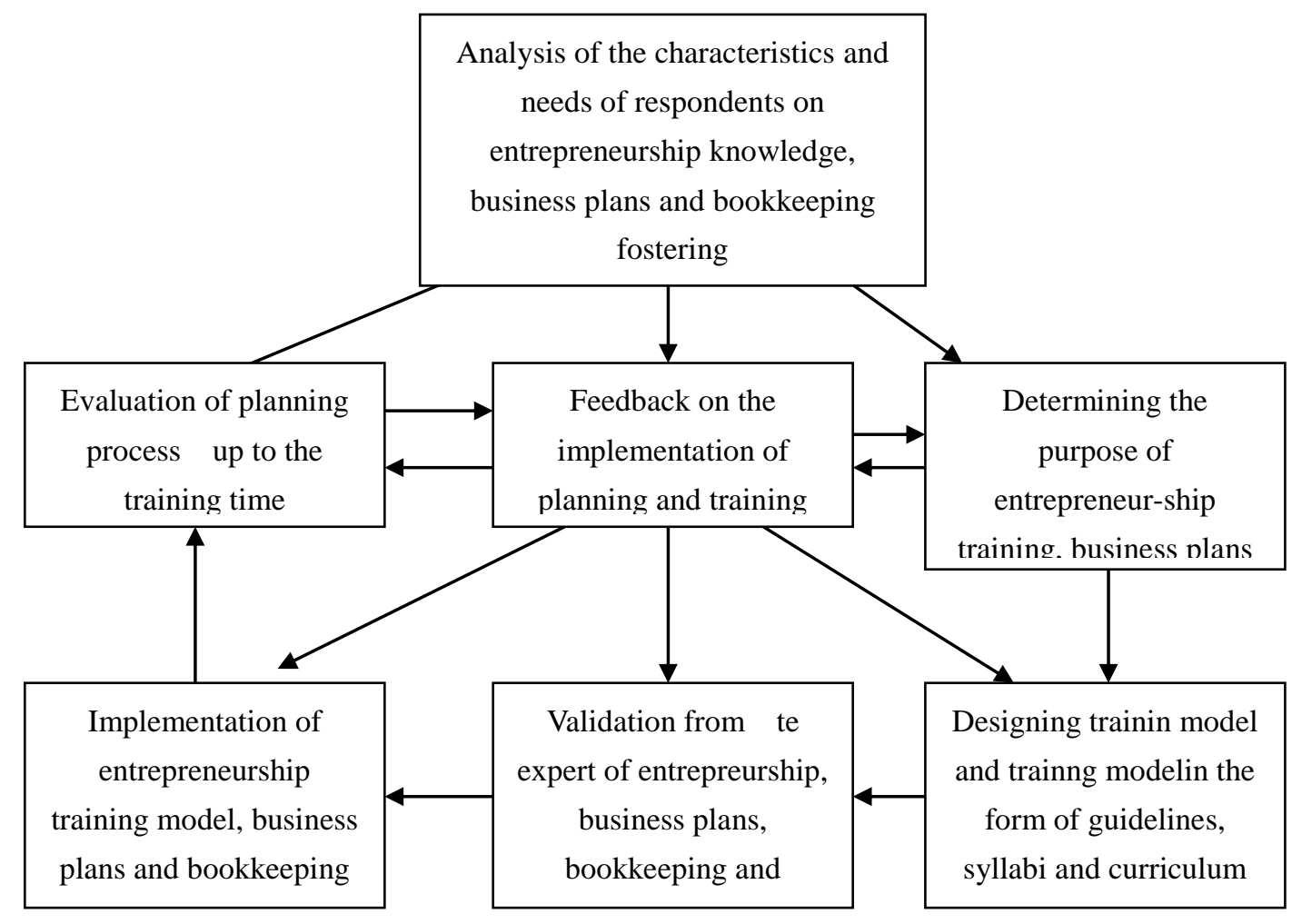

In more detail the development of the model above can be described as follows: (1) Identify the characteristics of respondents and the real needs of the respondents. Because the training model to be developed must involve respondents of furniture craftsmen, then respondents' characeristics need to know first. Efforts to investigate the characteristics of respondents is to avoid any deviation of the content, media, facilitator of the absorption ability of respondents candidates. This activity was conducted by researchers with the assistance of the village and the department of Cooperative and Small Business Development of Pasuruan regency and municipality. Identification is performed here by spreading the questionnaire in addition to in-depth interviews with the respondents. Data on individual characteristics were descriptively explained in the previous section. Dealing with the real needs of the respondents, the training undertaken by a particular institution often forget what is really needed by the prospective participant. If the executive coaches are not careful then the training will be useless. Therefore it is necessary to identify training materials needed by participants. Identification of the real needs conducted by distributing questionnaires, observations and interviews with potential participants and respondents with local community leaders. All these activities are done with the assistance of village, offices of Cooperation and Small Business Development and Pasuruan region and municipality. Data about the real needs of the respondents in descriptive way has been described in the previous section. (2) Determining the Purpose of the Training. In this study, the main goal is the development of training consisting of: The general objective of this research is to produce the Model of Entrepreneurship Training, business plans and bookkeeping fostering for furniture craftsmen in Pasuruan regency and municipality. While the specific objectives of research are: (1) To 
determine the implementation of Entrepreneurship Education and Training, business plans and bookkeeping (2) To find out the results of a comparative study on successful furniture businessman in Pasuruan municipality (3) To investigate the implementation of Business Plan validation evaluation of entrepreneurship training, business planning and bookkeeping participants (4) To produce implementation guidelines of entrepreneurial training, business planning and bookkeeping, supporting materials to make proposals / business plans of training participants. (3) Design and Development of Training Model. The term model viewed in Indonesian Language dictionary (Purwadarminta, 2002) is the creation of a training sample shall be composed of various components that support a training process. This developed training model comprised: (1) Training Manual. This training manual contains: Background of training imprtance, General Purpose and Special Purpose of training, scope of training. Furthermore, the General Guidelines for training which includes: Philosophy of training, training methods, examination of needs, resource person and facilitator as well as materials (2) The training syllabus comprising: Competency Standards that will be achieved as follows: At the end of training activity, participants were able to understand and use the entrepreneurship concept in the real world. In addition, the participants are expected to make a simple proposal of a viable business in a particular area. Besides, it also contains basic competency, indicators, learning experiences, training materials, time, materials and assessment. In more detail about this syllabus can be found in the appendix of the syllabus.

However, in general principal material can be described consisting of: (1) Entrepreneurship, which consists of: Definition of Entrepreneurship, the Requirements to become entrepreneurs, Advantages and disadvantages of being an entrepreneur (2) Business Plans consist of: Definition of business plan, purpose of making business plans, existing aspects in the business plan and its feasibility analysis (3) Bookkeeping with Accounting system which consists of: Diary, Ledger, Purchase and Sales Ledger, Journals and Ledger, Sheet and Financial Statements (4) Training methods applied are the methods of lectures, demonstrations, field visits, simulation, assignment and discussion.

\section{Expert Validation}

After going through the process of designing the model development ranging from the development of the model, the development of training manuals and the development of the training syllabus, furthermore it required validation of the experts either in relation to the development of the model, training manuals and training syllabus and training instruments. The experts involved in the validation process are from Economic Faculty of Brawijaya University Malang, namely Entrepreneurship and Business Plans experts; and the ones from Industrial Engineering Faculty, State University of Malang who are experts in the field of design and carpentry. From the expert validation result, there are inputs: (1) The first year of research concentrates better on the development of a training model by compiling a training manual, training syllabus and training curriculum. While in the second year, the research continues with the implementation of new training model. From this advice, the researchers also plan to submit a research proposal in the second year for the implementation of training model (2) Questionnaire made to capture data should be able to reveal the condition of the characteristics of respondents and the real needs of the respondents. Based on this input, the 
researchers tried to improve it in accordance with the advice of experts (3) Training Manual. Experts said that the manual is good enough and therefore was worthy of guidelines for training (4) Syllabus. Concerning the training syllabus experts suggested training methods should be practical, this means many examples of practice, training materials should be simple, not too scientific which in turn makes participants difficult to absorb. As respond to this suggestion researchers will try to arrange practical training materials (5) After arranging training guide and syllabus, this research is suggested to step on test level. The test was conducted on 30 furniture craftmen. The result showed that the level of knowledge, attitudes and skills of furniture craftsmen increased (by 75\%). It is seen from the initial test before the training and the final test after training.

\section{Discussion of Results}

In general, the findings of the study indicated that the respondents stated they are seldom following the training of entrepreneurship, business plans and bookkeeping for small businesses. From the results of research through the presentation of data in descriptive form especially regarding the real needs of the respondents, there is information that the respondents are also in high need of training in the field of entrepreneurship, business planning and bookkeeping. These results prompted researchers to develop a model of training in the field of entrepreneurship, business planning and bookkeeping that so far is still rarely carried out by others. If there is a development of the training model, it was only happed in official government agencies such as entrepreneurial training for employees to prepare for retirement (Jawa Pos, May 23, 2009), or the development of the training model among government entities, private or cooperative, which is more oriented on improving the performance of employees. The development of entrepreneurial training model has ever been developed by government agencies such as the department of industry or department of cooperatives and small business development. However, these trainings are not designed in a regular and systematic training guides, not having a clear syllabus. There is an impression that the trainings conducted by official agencies have just spending funds without any intensive post-training fostering, therefore they hope that through this first phase of research should be continued through the trial implementation of entrepreneurship training, business planning and bookkeeping fostering. Through interviews the information was obtained that the respondents stated they are confident that after the training they will get useful knowledge for the betterment of their businesses. The results of this study in fact is in accordance with the hope of Ginanjar (2000) that people need to be empowered through training but should be based on the real needs of society. On the other hand this research will enrich the community empowerment as according to Adi Sasono (2003) which states that if the government wants to drive the national economy then not only move abstract markets through stock exchange, or money market but must go through the economic empowerment of small communities (real economy) which must be preceded by training in the field of economic empowerment and after that to be supported with reasonable economical facilities such as crafting credit with low interest rates. Furthermore, Nikijuluw (2008) commented that so far according to the results of his research that a lot of the training conducted by official agencies or non-governmental organizations are not followed with a post-training coaching. The 
post-training coaching actually is very important role towards the empowerment of weak economy community.

This research can indeed serve as a model for reforming economic empowerment models that have been conducted in developing countries, including Indonesia. Dwivedi, Anju (2006), warned that the training model developed should be non-interactive and not one direction. Kenneth E. Bauzon (2013), said that experience shows empowerment model by distributing the funds for the poor did not bring any difference to the economy of society. The essence of real empowerment is to improve the quality of human resources through training in order to increase the capacity of the participants and will encourage them to carry out productive activities to improve their businesses, which in turn can improve their welfare. The same view was presented by Bird, Mary Jane (2014) that many failures of social empowerment occured in West African countries because Empowerment was identified as flushing of funds to the public. Money or fund is only one aspect to empower people but what much more important is designing a model of entrepreneurial training to increase their capacity so that they can be economically independent in the future. People who have always be given the funds will shape them into people who have beggar mental, while empowerment through increased their capacity will build a new culture that they are always willing to change their fate for the better one, without having to wait for funds from outside parties. Agpalo, Remigio, E (2012) suggested that because of this reason, political role of the government is to increase the capacity of small economic actors trained to become highly strategic. The government can play a role by providing funding and training institutions either managed by the State itself or can cooperate with other institutions such as non-governmental organizations or research institutes and community service of the college. Brown, Donald (2013) and supported by Covey, Stephen R. (2014) pointed out how New Zealand farmers and ranchers who have very successful effort by the intervention of the State and cooperative that always provide training to improve the capacity of farmers and ranchers in order to be more productive. Such empowerment model is able to build the productivity of farmers and cattle breeders in New Zealand. In the case of Indonesia, Kartasasmita (1998), supported by Sri Edy Swasono (2010) shows the success of agricultural development in Indonesia to conduct self-sufficiency in rice in the New Order era, the very important role is the instructors who provides training for farmers and ranchers to increase their capacity in conducting their activities. Finally Yamauchi C. (2014) stating why Japan is so self-sufficient in agriculture, this happens because the Japanese government did not carry out a policy to free distribute the money to farmers but farmers are empowered through education, training and counseling and subsidies, so it was not through direct funds model. Marcus A. (2014) stated that in order to support the further empowerment of communities after training it is necessary to set up micro-finance institutions which were managed by them with a system of collective responsibility to support their business development. The role of government here only as coaches, not as an executor. 


\section{Macrothink \\ International Journal of Learning \& Development \\ ISSN 2164-4063 \\ 2015, Vol. 5, No. 3}

\section{Conclusions and Suggestions}

\section{A. Conclusion}

From the results of the first phase research, it is inferred: (1) Almost all survey respondents of furniture craftmen as laborers a small number as the owner have low income levels at average, the majority of respondents have elementary and secondary school education, the quite high number of children they should cover, and they are in deep need of training in the field of entrepreneurship, business planning and bookkeeping develop their business. (2) The procedure of model development adopted Borg and Gall (2003) as follows: Research and collection of information, planning, early product development (draft models), early trials, products revision, limited field trials, model revision, final model. The results of research is a model of entrepreneurship training, mentoring and coaching bookkeeping for furniture craftsmen, which are arranged in the form of textbooks, which contains guidelines of entrepreneurship training, mentoring, and simple bookkeeping for furniture craftsmen.

\section{B. Suggestions}

From the conclusions, therefore it is suggested: (1) For furniture craftsmen who have the same characteristics as the subjects of research can use this model to improve the knowledge, attitudes and skills in managing their business;

(2) For the Ministry of Trade and Industry, this model can be used as a reference for coaching for furniture craftsmen in Indonesia.

\section{Refernces}

Agpalo, Remigio, E., (2012) Modernization, Development, and Civilization: Reflections on the Prospects of Political Systems in the First, Second and third Worlds dalam Kenneth E. Bauzon (ed),Development and Democratisation in the Third World: Myths, Hopes and Realities; Washington: Crane Russak

Bird, Mary Jane (2014 ), Entrepreneural Behavior, Singapore: Irwin Mc Grow Hill

Brown, Donald. (2013) "Poverty-Growth Dichotomy". Uner Kirdar dan Leonard Silk (eds.), People: From Impoverishment to Empowerment. New York: New York University Press.

Buchori, Mochtar. "Pengantar". (1993) Walter Fernandes dan Rajesh Tandon (eds.) Riset Partisipatoris- Riset Pembebasan. Penyunting: Wardaya dan Hardiman. Gramedia Pustaka Umum.

Covey, Stephen R. (2014), The Seven Habits of Highly Effective People. Edisi Revisi, Dialihbahasakan oleh Lynda saputra, Jakarta: Binarupa Aksara.

Dinas Infokom. Jatim. 2001. Profil Jatim (online). (http: //www.d.Infokom-Jatim).

Dwivedi, Anju (2006), Merancang Pelatihan Partisipatif Untuk Pemberdayaan, Metodologi Pelatihan Partisipatif, Terjemahan Bebas dari Buku Methode of Participatory Training, Penerbit Pondok Edukasi, Yogjaharta. 


\section{Macrothink \\ International Journal of Learning \& Development \\ ISSN 2164-4063 \\ 2015, Vol. 5, No. 3}

Friedman, John, (2012) Empowerment: The Politics of Alternative Development. Cambridge: Blackwell,

Josephine, Wuri (2014), UKM danPerannya dalam Menanggulangi Kemiskinan, Reposisi Usaha Mikro Kecil Dan Menengah Dalam Perekonamian Nasional, Penerbit Universitas Sanata Dharma, Yogjakarta.

Kartasasmita Ginanjar, (1998) Pembinaan Program dan Pendampingan Pokmas IDT; Jakarta: Badan Perencanaan Pembangunan Nasional - Departemen Dalam Negeri, 1998.

Kartasasmita, Ginandjar, (1998) Ekonomi Rakyat: Memadukan Pertumbuhan dan Pemerataan; Jakarta: CIDES, 1995.

Kartasasmita, G., Pembangunan Menuju Bangsa yang Maju dan Mandiri: Sebuah Tinjauan Mengenai Berbagai Paradigma, Problematika, dan Peran Birokrasi dalam Pembangunan; Pidato Penerimaan Penganugerahan Gelar Doctor Honoris Causa Dalam Ilmu Administrasi Pembangunan dari Universitas Gajah Mada, Yogyakarta, 15 April 1998.

Kartasasmita G., Pemberdayaan Masyarakat: Sebuah Tinjauan Administrasi; PidatoPengukuhan Jabatan Guru Besar dalam Ilmu Administrasi pada Fakultas Ilmu Administrasi Pemangunan Universitas Brawijaya; Malang, 27 Mei 1998.

Kenneth E. Bauzon (2013), Development and Democratisation in the Third World:

Marcus A. (2014), Yogendra Prosad Acharya, Local Culture, Local Power: Micro finance in Rural Nepal, Working Paper No. 01/05, 2005, Melbourne University Private.

Swasono, Sri-Edi (2010), "Kemandirian dasar Martabat bangsa", Pidato ilmiah dalam Rangka Diesnatalis Universitas Gajayana Malang, September 2003

Yamauchi C. (2014), Evaluating Poverty Alleviation, Program for Training in International Population Studies, California Centre for Population Research from frem The William and Flow hewlettt Foundation, May 2014 